\title{
ANALYSIS OF THE RENEWABLE ENERGY POTENTIAL IN YAMBOL REGION
}

\author{
Nely Georgieva, Georgi Georgiev, Elena Balcheva \\ Trakia University, Faculty of Technics and Technologies \\ 38 "Graf Ignatiev" str., 8602, Yambol, Bulgaria \\ e-mail: nely.georgieva@trakia-uni.bg
}

\begin{abstract}
Implementation of the European policy on renewable energy sources according new aspects which are presented also in new Sustainable Development Program in 2030 is very important respect for ecology and environmental protection. The European Union (EU) has set ambitious climate and energy targets for 2030, including an EU-wide target for renewable energy of at least 27\% of final energy consumption. As a member of the European Union, Bulgaria is committed to maintaining and implementing European policies. The aim of this report is to make a profound overview study of the installed capacity of renewable energy on the territory of Bulgaria and the Yambol region.
\end{abstract}

Keywords: Renewable energy, sources, ecology.

\section{INTRODUCTION}

The global energy crisis will develop and deepen over the coming decades. Key factors in this process are increased energy consumption and the gradual depletion of nonrenewable energy sources (oil, gas, coal, etc.). Analysis of the world's leading experts indicate that even with decreased consumption, the known deposits of oil will be exhausted to 2045, and natural gas - to 2075. Over the past few years, European legislators have faced a number of challenges in energy policy.

The consequences of climate change for the environment and economies are unavoidable, energy security in Europe being jeopardized due to the high dependence on energy imports. Moreover, the current financial and economic crisis is threatening economic growth and employment. In this context, the Directive on the promotion of the use of energy from renewable sources (RES) (2009/28/EC) [1] is an important event in European legislation. By setting a common target for a $20 \%$ share of renewable energies in the final energy consumption of the 27 EU Member States by 2020, the directive provides the necessary political support for the renewable energy market, which has huge potential for growth and creating new jobs. The directive obliges each of the 27 Member States to develop a National Renewable Energy Action Plan (NREAP) on the basis of the model provided by the European Commission, creating preconditions for the harmonization of their national laws [2, 3]. The European Union could achieve the overall objective for 2020 only through the development of ambitious and concerted national action plans.

The target for Bulgaria, proposed by the European Commission, is $16 \%$ of the total final energy consumption in the country in 2020 to be from renewable energy sources, as the country receives the lowest additional increase (6.6\%) from the rest of the Member States. At present, the National Energy Strategy of the Republic of Bulgaria until 2020 places priority on all possible sources of energy, which at best is unrealistic. An analysis of the possibilities shows that Bulgaria has the greatest potential for wind [4, 5], biomass and hydropower. In practice, however, Observ'ER [6] statistics for 2016 indicate that the largest installed capacity of RES in Bulgaria is from photovoltaic installations. It's still fairly expensive technologies,

IRTIIE Vol. 5, No. 2, 2017 ISSN 1314-8788 (print), ISSN 1314-8796 (online), doi: 10.15547/artte.2017.02.007 
leading to increased costs of green energy supplement in the monthly energy bills of consumers and incite them pessimistic towards the use of renewable energy sources.

The aim of the report is to establish the state of the installed capacity of RES in Bulgaria and the share of the Yambol region to implement the policy for wider use of green energy to meet the objectives set in the 2030 Agenda for Sustainable Development [7] and the European program "A sustainable European future: The EU response to the 2030 Agenda for Sustainable Development" [8].

\section{EXPOSE}

According to the annual report of Observ'ER [6,9] on the state of renewable energy in Europe for 2015 and 2016, the situation in Bulgaria is as follows (Table 1) and graphically presented in Figure 1:

Table 1. Installed capacity in Bulgaria for some RES for the period 2013-2015

\begin{tabular}{|l|r|r|r|}
\hline \multicolumn{1}{|c|}{ Type of RES } & 2013 & 2014 & 2015 \\
\hline Wind Installations, MW & 676 & 686,8 & 700 \\
\hline Photovoltaic installations, MW & 1018,2 & 1020,4 & 1026 \\
\hline Small hydropower, MW & 283 & 283 & 331 \\
\hline Thermal energy for direct use, MWth & 83,1 & 83,1 & 83,1 \\
\hline Solar installations, MWth & 5600 & 5600 & 5600 \\
\hline Geothermal Energy, MWth & 83,1 & 83,1 & 105,6 \\
\hline Heat pumps, the number & 366 & 532 & 532 \\
\hline Biogas, ktoe & 12 & 20 & 27 \\
\hline
\end{tabular}

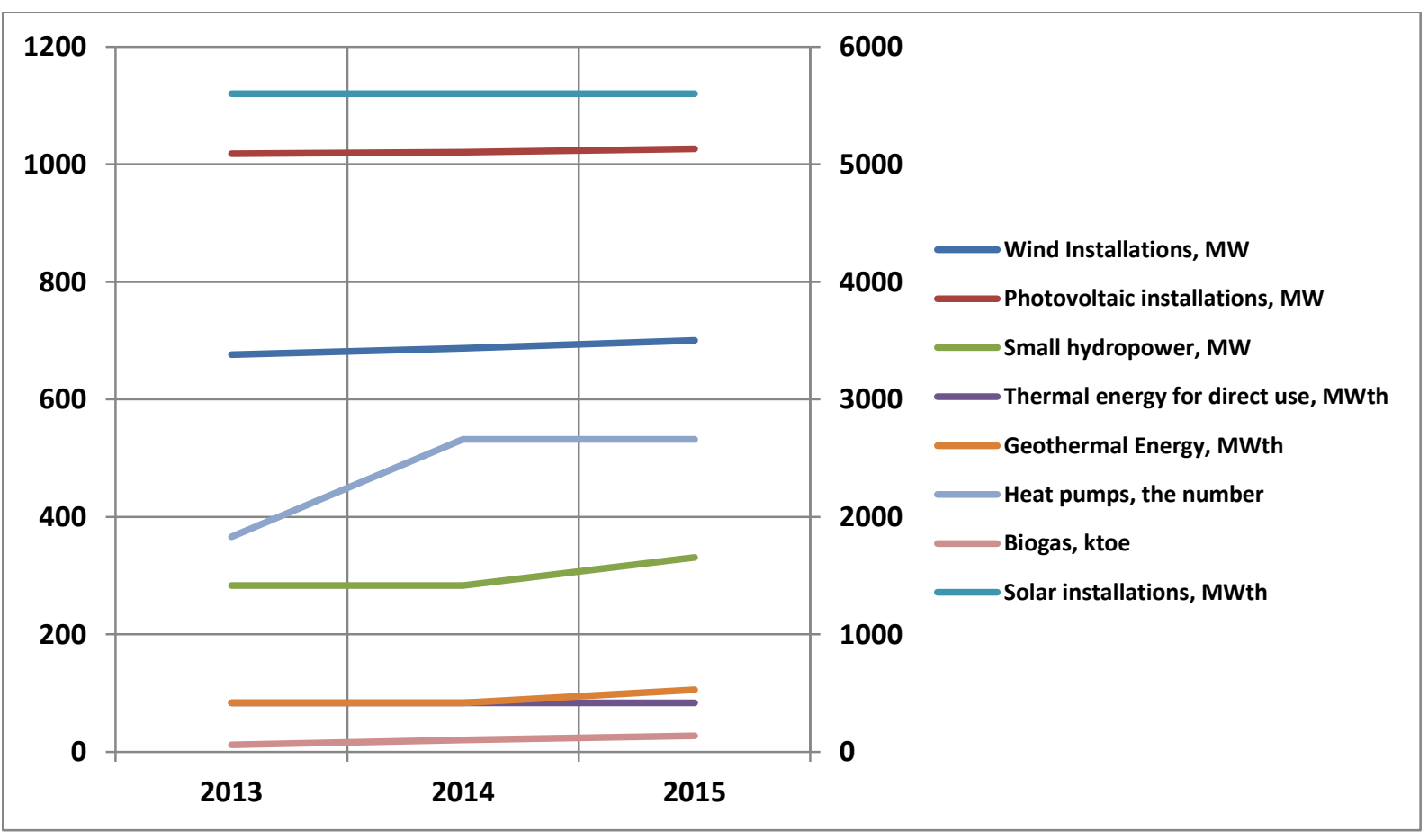

Figure 1. Installed capacity in Bulgaria for some RES for the period 2013-2015

IRTIII Vol. 5, No. 2, 2017 ISSN 1314-8788 (print), ISSN 1314-8796 (online), doi: 10.15547/artte.2017.02.007 


\section{IRTITIE}

Ipplied Reseitriches in Teednicis, Technologies ind Bductition

Journal of the Faculty of Technics and Technologies, Trakia University https://sites.google.com/a/trakia-uni.bg/artte/

From the provided information, the installed capacity of certain types of RES - wind installations, geothermal energy, heat pumps, small hydropower plants, and photovoltaic plant biogas plants can be monitored. There is no increase in installed capacity for thermal energy for direct use and solar installations over the period considered. It should be noted that for some types of RES the installed capacity in Bulgaria is very small, e.g. energy from the processing of solid and household waste, there aren't installed power from concentrated solar installations and ocean / marine energy. A survey of the installed RES in the three municipalities of the Yambol region for the period 2005 - 2016 was made, according to data from the National Statistical Institute [10]. The available information is only for part of Observ'ER types of RES - photovoltaic, wind, biogas and water installations. The collected information includes data on the type, size and location of installed power, year of commissioning. Figure 2 presents information on the number of installed RES in the three municipalities of the Yambol region - Yambol, Tundja and Straldja.

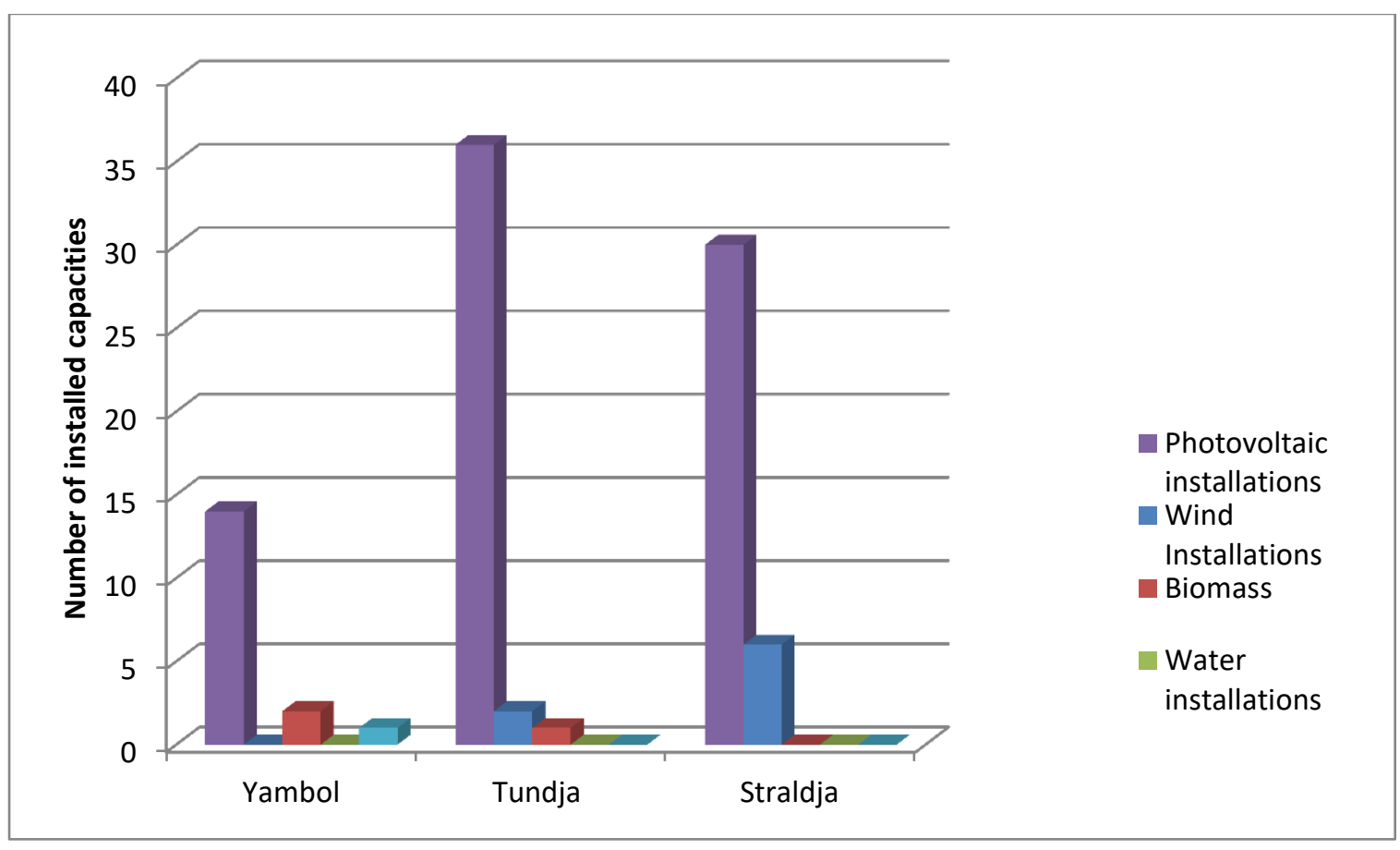

Figure 2. Number of installed RES capacities in the Yambol region

From the analysis it was found that there are no installed water capacities in the Yambol region, which is explicable according to the geographical location. With the same consideration, it can be commented on the fact that the most installed capacities are photovoltaic installations. The wind farms are mainly concentrated in the municipality of Straldja, which is closest to Stara Planina, and part of the air currents in the Balkan Mountains are captured on its territory.

The greater number of installed RES capacities are located in Tundja Municipality, except for wind farms.

The still installed biomass processing capacities in the Yambol region are very small. The region has a predominantly agricultural production whose waste could be successfully used to obtain heat or electricity power.

IRTTIE Vol. 5, No. 2, 2017 ISSN 1314-8788 (print), ISSN 1314-8796 (online), doi: 10.15547/artte.2017.02.007 


\section{IRTIIE}

Ipplied Researl reses in Technics, Technologies and Bduration

Journal of the Faculty of Technics and Technologies, Trakia University https:///sites.google.com/a/trakia-uni.bg/artte/

Table 2 gives data on the total capacity of the installed RES installations in the Yambol region for the period 2005-2016. The municipality with the most installed RES capacities is Straldja, mainly due to the photovoltaic systems. They are least in Yambol Municipality, but here, besides photovoltaics, there is a biodiesel installation, the only one on the territory of the district and the main part of installations for biogas.

Table 2. Installed RES in municipalities in Yambol region for the period 2005-2016

\begin{tabular}{|c|c|c|c|c|c|c|}
\hline RES & 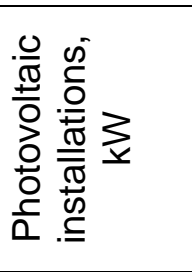 & 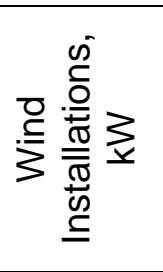 & 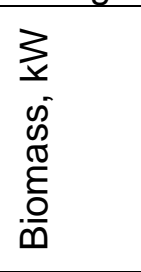 & 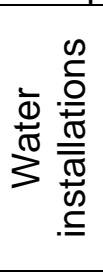 & $\begin{array}{l}\bar{\Phi} \\
\stackrel{\Phi}{O} \\
\dot{0} \\
\dot{0}\end{array}$ & 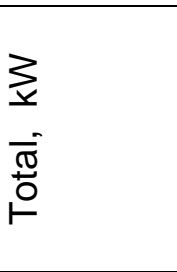 \\
\hline Yambol & 12249,34 & 0 & 1900 & 0 & 1050 & 15199,34 \\
\hline Tundja & 58872,77 & 2200 & 330 & 0 & 0 & 61402,77 \\
\hline Straldja & 82524 & 3600 & 0 & 0 & 0 & 86124 \\
\hline
\end{tabular}
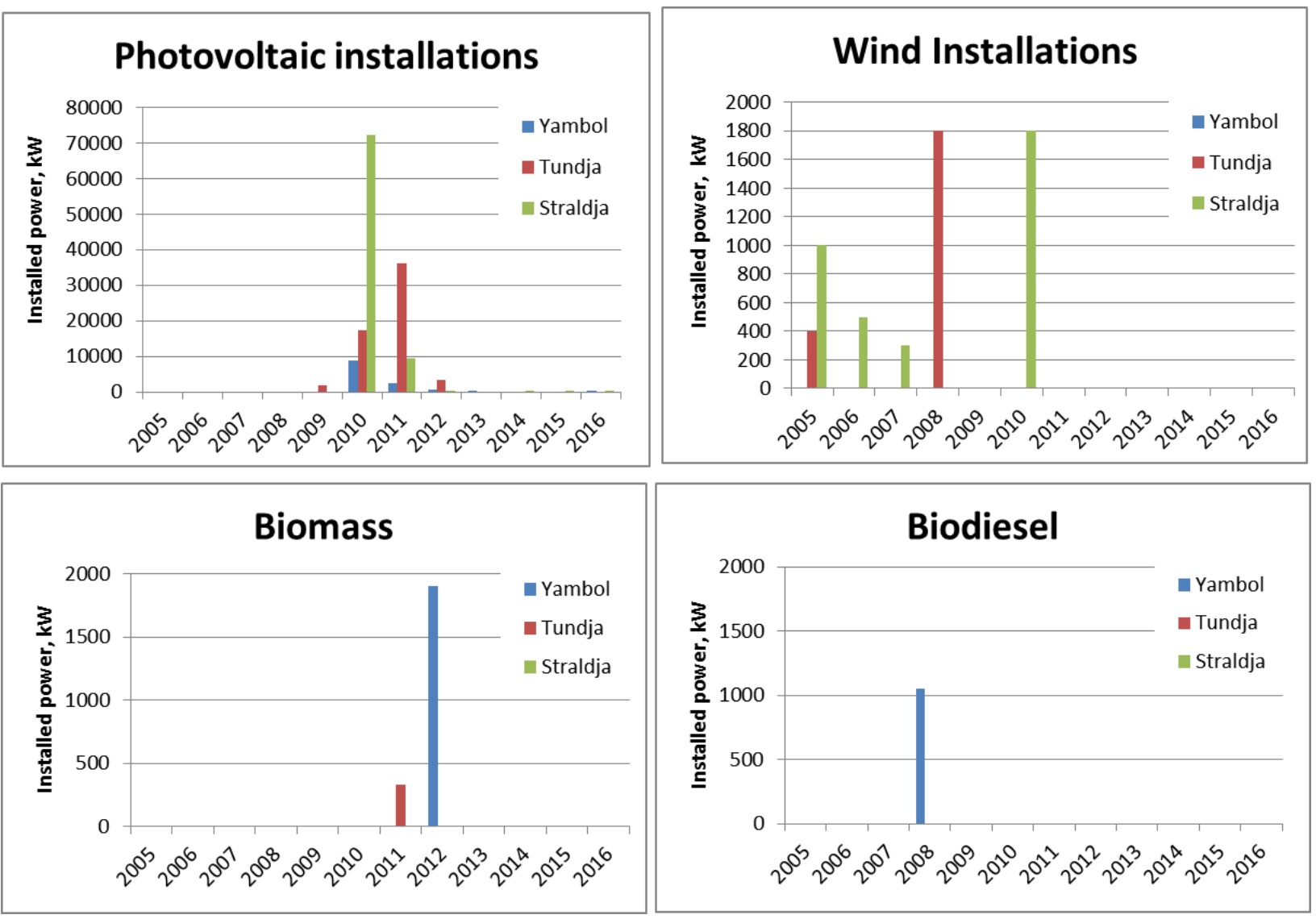

Figure 3. Dynamics of installed renewable energy capacity in the Yambol region

IRTTIE Vol. 5, No. 2, 2017 ISSN 1314-8788 (print), ISSN 1314-8796 (online), doi: 10.15547/artte.2017.02.007 


\section{IRTITE}

Ipplied Resseirlches in Teechnics, Technologies and Bductation

Journal of the Faculty of Technics and Technologies, Trakia University https://sites.google.com/a/trakia-uni.bg/artte/

The total installed capacity of photovoltaics in the Yambol region is $153646,11 \mathrm{~kW}$, which is $15 \%$ of the installed capacity in Bulgaria. This is mainly due to photovoltaic installations. The relatively high percentage for Bulgaria is due to the good geographic location of the region in terms of number of sunny days. In Figure 3 is presented information about the size of the installed RES capacities in years in the three municipalities.

The information provided shows that the most renewable capacities have been built in 20082012, after which there is a stagnation. This is probably due to the fact that European funding is usually used to finance such projects, as are the various incentives when buy up green energy from producers. It can be expected that with the start of the new programming period new RES capacities will be built.

\section{CONCLUSION}

The following conclusions can be drawn from the study and analysis of the results obtained:

- In general, both for Bulgaria and Yambol region, the largest share of renewable energy is from photovoltaic installations. This technology is still relatively expensive and this leads to an increase in the price of the green supplement, which is paid by the consumers of the National Electricity Company.

- There are no suitable conditions in Yambol for the use of certain RES, such as water, as the area is poor for this resource.

- Yambol is predominantly an agricultural region, many biological waste remain after the processing of the agricultural areas. In Yambol municipality there are a number of canning and food industry companies that dispose of organic waste. This shows that the Yambol area has a significant biomass potential. There are some projects that aim to build small bioreactors for the respective companies emitting bio-waste. It is necessary to carry out in-depth studies in this area of absorption of the potential raw materials for the production of green energy.

- With regard to government policy to support different types of RES, an in-depth analysis of their potential needs to be made and appropriate incentive measures should be put in place for those RESs that are profitable, for example increasing capacity to produce biodiesel has no positive effect, which has been established globally. This suggests limiting investment in this direction.

\section{REFERENCES}

[1] Directive 2009/28/EC of the European parliament and of the council of 23 April 2009 on the promotion of the use of energy from renewable sources and amending and subsequently repealing Directives 2001/77/EC and 2003/30/EC.

[2] National renewable energy action plan, drawn up in accordance with the template for national renewable energy action plans as set out in Directive 2009/28/EC of the European Parliament and of the Council, 20 April 2011, http://pvtrin.eu/assets/media/PDF/EU_POLICIES/National\%20Renewable\%20Energy\%2 0Action\%20Plan/203.pdf,\%20 available 04.07.2017.

[3] Binev I., Analysis of Bulgarian regulations for heat transfer of buildings ARTTE, vol.4 No4, 2016, ISSN 1314-8796, pp.317-321.

[4] Sebastian Noethlichs, the RES market in Bulgaria has great potential but needs established rules, Energy Review - issue 3, 2010, September.

IRTIII Vol. 5, No. 2, 2017 ISSN 1314-8788 (print), ISSN 1314-8796 (online), doi: 10.15547/artte.2017.02.007 


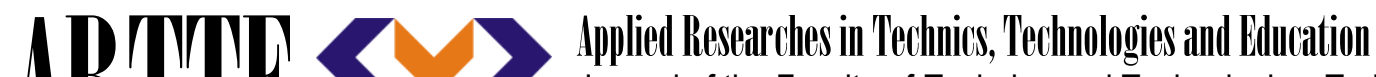 Journal of the Faculty of Technics and Technologies, Trakia University https://sites.google.com/a/trakia-uni.bg/artte/}

[5] Ljubcho Trichkov, Potential of Biomass in Bulgaria as a Renewable Energy Resource Present and Prospects for its Utilization, Management and sustainable development 1/2007 (16), p.60-77.

[6] The state of renewable energies in Europe, Edition 2016, 16th EurObserv'ER Report, https://www.eurobserv-er.org/16th-annual-overview-barometer/.

[7] The state of renewable energies in Europe, Edition 2015, 15th EurObserv'ER Report, https://www.eurobserv-er.org/15th-annual-overview-barometer/.

[8] https://sustainabledevelopment.un.org/frameworks/parisagreement.

[9] A sustainable European future: The EU response to the 2030 Agenda for Sustainable Development, General Secretariat of the Council, 20 June 2017.

[10] http://www.nsi.bg/. 